\title{
Diversity of Bugulidae (Bryozoa, Cheilostomata) colonizing artificial substrates in the Madeira Archipelago (NE Atlantic Ocean)
}

\author{
Patrício Ramalhosa ${ }^{1 *}$, Javier Souto ${ }^{2,3}$ and João Canning-Clode ${ }^{1,4,5}$
}

\begin{abstract}
Until very recently the Madeira Archipelago registered a total of eight Bugulidae species. In the present study we include descriptions of seven Bugulidae species, now with Scanning Electron Microscopy images, with four new records for the Archipelago: Bugulina fulva and Bugulina simplex for Madeira Island and Bugula neritina and Crisularia gracilis for the neighbouring Island of Porto Santo. Furthermore, we report the correction of the previous identification of Bugulina calathus minor earlier reported from Funchal harbour in 1998, now as Bugulina flabellata. This study is part of an ongoing monitoring program for detecting non-indigenous species in all marinas from the Madeira archipelago, between 2007 and 2015. Specimens were collected in previously deployed PVC settling plates, marina pontoons, and also on recreational hull vessels while performing dry dock inspections at a local shipyard. Our study reveals that the Madeira archipelago now registers a total of ten Bugulidae species, contributing therefore to the total bryozoan fauna of the Archipelago, now with more than 100 records. These numbers could increase, as Madeira is considered to be a "hotspot" for bryozoan diversity when compared to other nearby regions. Finally, hull fouling is considered as the most likely vector of introduction for the non-indigenous species of Bugulidae detected in Madeira.
\end{abstract}

Keywords: Biofouling, First record, Marinas, Madeira Island, Non-indigenous species, Recreational vessels

\section{Background}

The introduction of non-indigenous species (NIS) remains today a global threat to biodiversity in coastal marine ecosystems [e.g. 1, 2]. This phenomenon has significantly increased in the past years as maritime traffic represents one of the main vectors contributing to the spread and establishment of NIS worldwide, facilitating the transport of species in ship hulls and ballast water [3-5]. Floating docks and other artificial substrates are very common in bays and estuaries, particularly in shipping areas and marinas are highly relevant for detecting new NIS arrivals [6-8]. The occurrence of artificial pontoons around the world may favour the dispersal of NIS, by providing stepping stones that allow colonization into new areas $[9,10]$. In fact, marinas and harbours have

\footnotetext{
*Correspondence: patramalhosa@gmail.com

${ }^{1}$ MARE - Marine and Environmental Sciences Centre, Estação de Biologia Marinha do Funchal, Cais do Carvão, 9000-107 Funchal, Madeira, Portugal Full list of author information is available at the end of the article
}

become an ideal study system for rapid assessment surveys (RAS) of NIS [e.g. 7, 11-13].

The Madeira archipelago is located Southwest of continental Europe and $700 \mathrm{~km}$ off the Moroccan coast, with a strategic geographic position in the Atlantic Ocean. Historically, the archipelago has provided an important passage route for many ships between Europe and the Caribbean, American and African continents. Today most of the maritime traffic comes from tourist cruise ships and sailing yachts for re-fuel, and rest stops from different parts of the world [14]. The diversity and distribution of fouling NIS in Madeira Island, North-eastern Atlantic Ocean, has received some attention in recent years due to on-going monitoring surveys, particularly in marinas on the southern coast of Madeira Island. As a result, several new species have been detected and inventoried [15-18], including new undescribed bryozoan species [19].

The phylum Bryozoa, (Ectoprocta) often known as moss animals, is a very diverse group with approximately 
5900 living species [20, 21] and 15,000 fossil records [22]. Bryozoans are mostly sessile, colonial, filter-feeder organisms that can be found living on a variety of different natural and artificial substrates such as rocks, floating pontoons, buoys or ropes [19, 23].

In the mid nineteenth and early twentieth centuries the pioneer work of Busk [24-28], Hincks [32], Johnson [31], Waters [30], and Norman [29] in surveying the bryozoan fauna of the shallow waters of Madeira resulted in a list of 139 species. Since then, a few species were added to this list, with most of the new records detected in the twentieth century [33-36]. In recent years, new records of bryozoans have been reported for Madeira Island [15, 17, 19, 37]. Nevertheless, Berning [38] indicates that the known bryozoan species list for the Madeira archipelago is likely far from reflecting the true species richness for this group when compared to other coastlines. The author further considers the $250 \mathrm{~km}$ coastline of the Madeira archipelago a 'hotspot' of bryozoan diversity, when compared to the 260 species known from the $1600 \mathrm{~km}$ of the Galician coastline [38].

The genus Bugula Oken, 1815, sensu lato, comprises around 90 valid species [39]. Individuals belonging to this group can be found living in shallow waters [40, 41], and also in deeper waters of continental shelf [42, 43]. Recently, an extensive revision using molecular and morphological techniques was performed for Bugula sensu lato resulting in four valid genera, Bugula sensu stricto, Bugulina [44], Crisularia [44] and Virididentula [42]. Several of these species, such as Bugula neritina [45], Virididentula dentata [46] and Bugulina stolonifera [47], have a widespread distribution and are abundant among fouling communities [40, 48-50].

To date, eight Bugulidae species have been detected in the Madeira archipelago: Bugula neritina [29], Bugulina stolonifera [17], Bugulina calathus minor [36, 51], Bugulina ditrupae [24], Bugulina avicularia [29, 45], Crisularia gracilis [24], Crisularia plumosa [29, 52], and Virididentula dentata $[17,29]$.

The present study aims to review a complete list of the Bugulidae species colonizing artificial substrates in the Madeira archipelago. In this paper, we include descriptions of seven Bugulidae species with Scanning Electron Microscopy (SEM) illustrations, including four new records: Bugulina fulva [47] and Bugulina simplex [53] for the Madeira Island and Bugula neritina and Crisularia gracilis for the neighbouring Porto Santo Island. Furthermore, we report here the correction of the previous identification of Bugulina calathus minor earlier reported from Funchal harbour in 1998, now as Bugulina flabellata [44] for the Madeira Island.

\section{Methods}

In 2006 we initiated a NIS monitoring program in a local marina located along the South-eastern coast of Madeira Island $[17,54]$. We later expanded this study by adding a second marina in 2010, and two additional marinas in 2013 [16, 18]. Currently, our NIS monitoring program covers all four main marinas of the archipelago: Calheta $\left(32^{\circ} 43^{\prime} \mathrm{N}, 17^{\circ} 10^{\prime} \mathrm{W}\right)$, Funchal $\left(32^{\circ} 38^{\prime} \mathrm{N}, 16^{\circ} 54^{\prime} \mathrm{W}\right)$, Quinta do Lorde, Caniçal $\left(32^{\circ} 44^{\prime} \mathrm{N}, 16^{\circ} 42^{\prime} \mathrm{W}\right)$, and Porto Santo Island $\left(33^{\circ} 03^{\prime} \mathrm{N}, 16^{\circ} 18^{\prime} \mathrm{W}\right)$ (Fig. 1a-d). Funchal was the first marina being constructed in 1995 with the capacity of 260 berths, followed by Quinta do Lorde in 2002 with 264 berths, Calheta in 2004 with 300 berths, and Porto Santo Island in 2006 with the capacity of 139 berths.

For assessing NIS diversity, we have deployed 10 polyvinylchloride $(P V C)$ settling plates $(14 \times 14 \times 0.3 \mathrm{~cm})$ at approximately $1 \mathrm{~m}$ depth from pontoons in all four marinas of the Madeira Archipelago (see detailed methods in Canning-Clode, Fofonoff [55] and Ramalhosa, Camacho-Cruz [16]. At every 3 months, plates were retrieved from the field and examined to determine species richness. During each sampling event, plates were carefully examined using a stereo microscope (Leica Wild-M3 Heerbrugg), and specimens from settling panels were photographed using a Sony DSC-W55 camera. Samples were collected from different marina sites (Fig. 1a-d; Table 1), and preserved in $95 \%$ ethanol. For the purpose of this analysis, however, we are only reporting the presence of Bugulidae species collected and identified until March 2015. Selected specimens were deposited at Museu de Historia Natural do Funchal (MMF), Madeira, Portugal.

Additionally to settling plate deployment, we also initiated in 2013 dry dock inspections (DDI) on yacht hulls at a local shipyard (REPMaritima, www.repmaritima.com) for monitoring NIS arrivals via hull fouling. The ship's hull was photographed after being raised from water, at three different areas (bow, beam and stern) with a quadrate $(20 \times 20 \mathrm{~cm})$, using a Canon A620 camera. Species inspections were performed by personal observations, and unknown species samples were taken for later species identification. Furthermore, we collected further information concerning vessel history from yacht owners through questionnaires. These questionnaires aimed at getting information regarding vessel identification (i.e. name, nationality, home port, hull material and length of the boat), last port of call, dry docking (i.e. how often does the boat goes into a dry dock and whether fouling was removed), and hull maintenance history (i.e. which antifouling paint was last used and when was the last antifouling renewal). In this context, we have surveyed a 

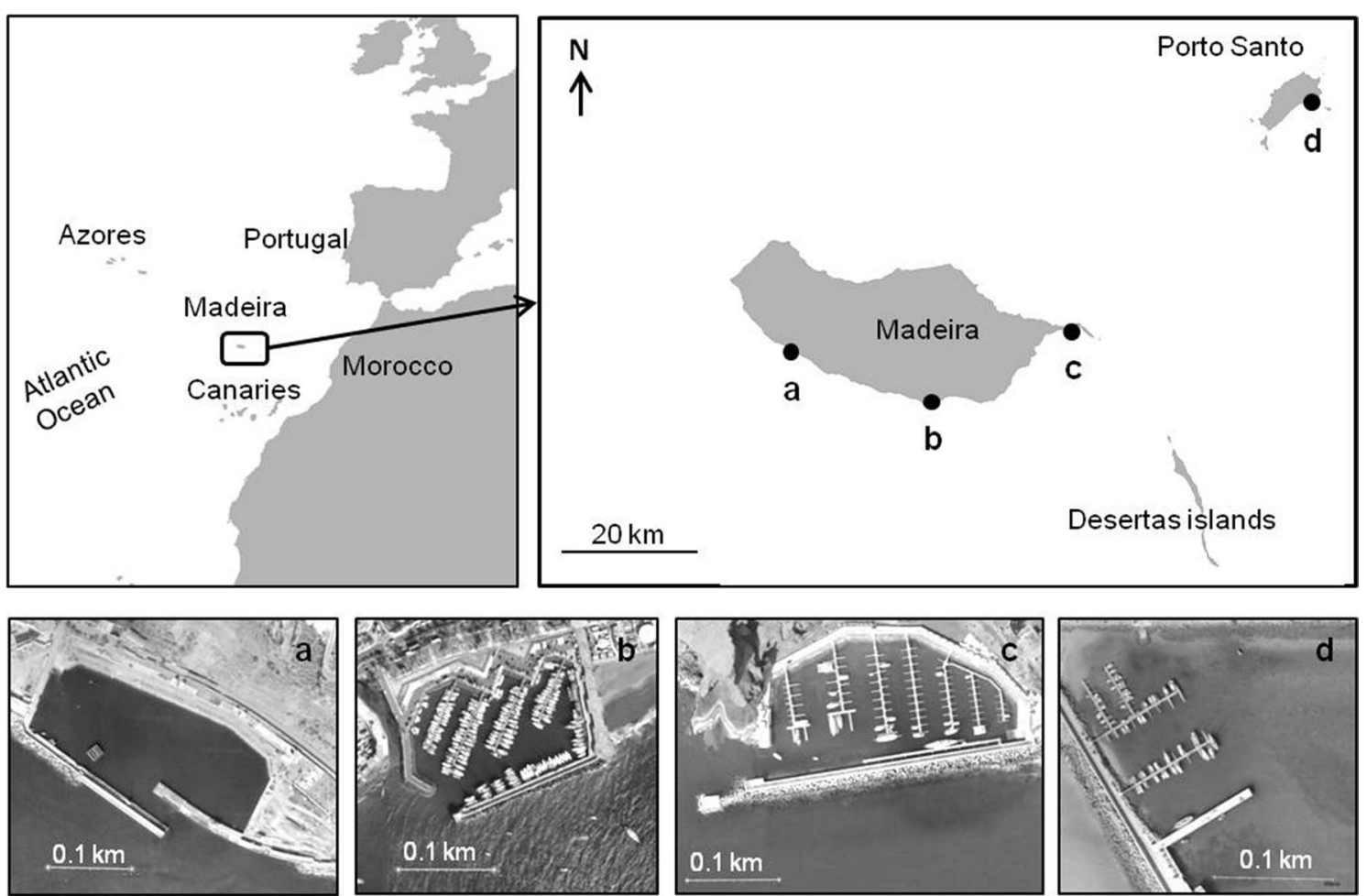

Fig. 1 Map illustrating the Madeira Archipelago with the location of the four study sites: a Marina da Calheta; b Marina do Funchal; c Marina da Quinta do Lorde and $\mathbf{d}$ Marina do Porto Santo

total of nine vessels from 2013 to 2015 where five were foreign with homeports in the North Sea and North Atlantic, while four were domestic.

Bugulidae specimens collected from harbours and DDI were later examined with scanning electron microscopic (SEM) photographs taken in a FEI Inspect S50 SEM using uncoated material at the University of Vienna, Austria. SEM was used with a back-scattered electrons detector in low vacuum mode. Part of the samples was exposed to an ultrasound bath, bleached by sodium hypochlorite and air dried for SEM examination. Measurements (in $\mathrm{mm}$ ) were taken with the software Image ${ }^{\circledR}$ [56] on the SEM photographs and are indicated in the descriptions of each species. Average measurements are included in $\mathrm{mm}$ while minimum, maximum data, and the number of measurements attained are included between brackets.

Finally and to complement this study, we conducted a comprehensive literature survey on previous records of Bugulidae species present in the Madeira archipelago. All species detected in settling plates, DDI and found in literature surveys were assigned to one of three categories of biogeographically distribution: native, NIS or cryptogenic (unspecified native origin, and unknown whether native or NIS), in accordance to literature and several current databases [57-60].

\section{Results}

In this study we report the presence of seven species: Bugula neritina, Bugulina flabellata, Bugulina fulva, Bugulina simplex, Bugulina stolonifera, Crisularia gracilis and Virididentula dentata in four marinas of the Madeira archipelago (Table 1). From these seven species, four are reported here as new records to the archipelago, with two for Porto Santo Island with B. neritina detected in 2013 and C. gracilis in 2015; and two for Madeira Island, with the detection in 2013 of B. fulva and B. simplex for the marinas of Funchal and Quinta do Lorde, respectively.

Furthermore, our literature survey found records of five species of Bugulidae: Bugulina calathus minor, Bugulina avicularia, Bugulina ditrupae, Crisularia gracilis for Madeira, and Crisularia plumosa for Porto Santo (see Table 1).

However, Bugulina calathus minor (sample MMF31648), earlier reported from Funchal harbour in 1998 by Alves and Cocito [36], was carefully examined during this study and is now recognised as co-specific with our B. flabellata samples. Nevertheless, species found in our literature survey were not detected in our samples except for C. gracilis and B. flabellata. Consequently, B. flabellata was therefore detected in Funchal harbour in 1998 [36], 


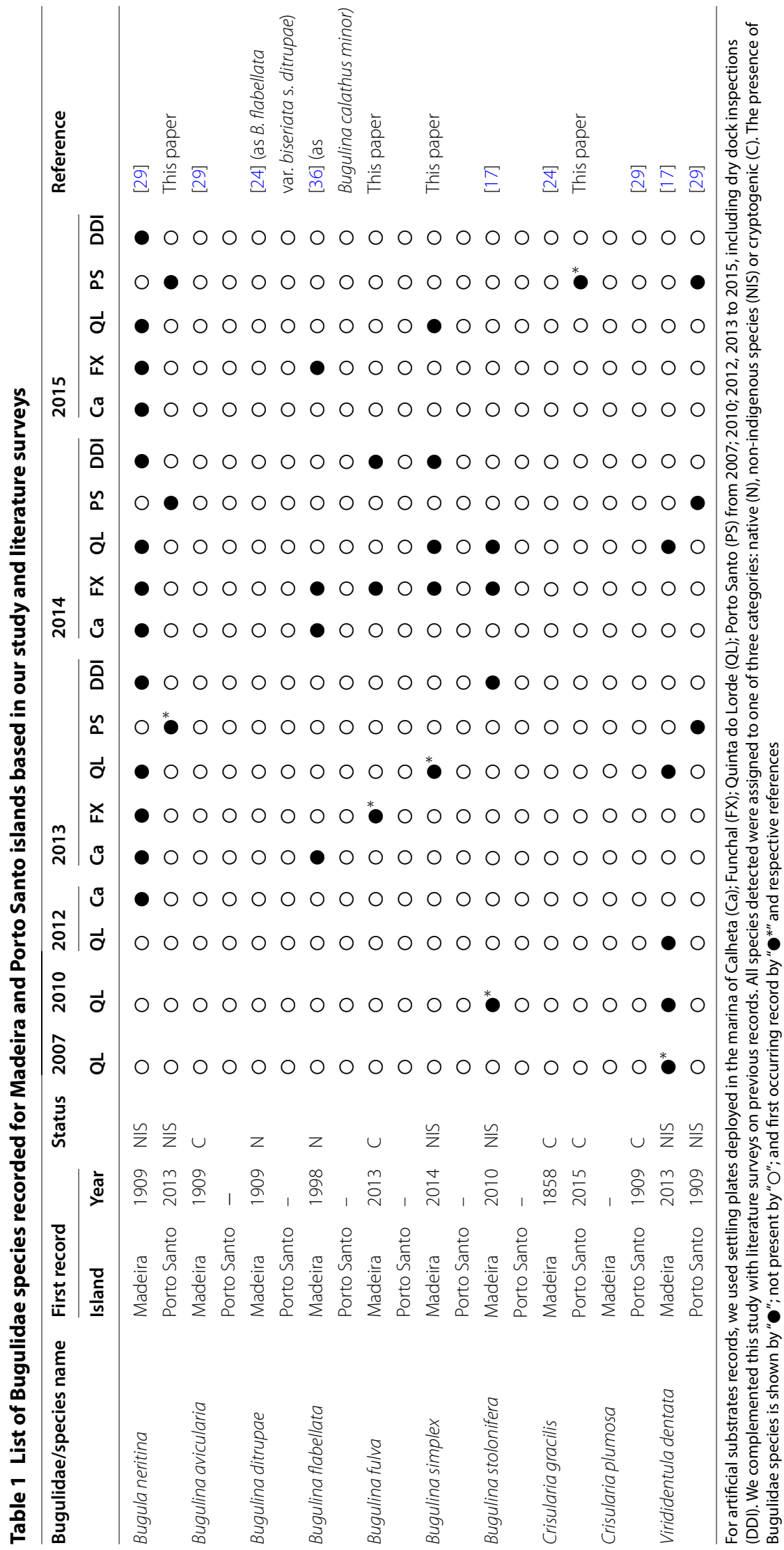


and recently in the marinas of Calheta and Funchal in 2013 and 2014 respectively (see Table 1).

Finally, as a result of our dry dock inspections, we have found records of four Bugulidae species: B. neritina, $B$. stolonifera, B. fulva and B. simplex. The most prevalent of these species was Bugula neritina, found in seven vessels (in four foreign vessels and in three domestic vessels). Bugulina stolonifera was present in one recreational vessel with Northern Europe origin. Finally, Bugulina fulva and Bugulina simplex were both detected in one local recreational vessel from Funchal. Next, we describe the seven Bugulidae species detected in artificial substrates in the Madeira archipelago from 2013 to 2015:

Order CHEILOSTOMATIDA Busk, 1852

Family BUGULIDAE Gray, 1848

Genus Bugula Oken, 1815

Bugula neritina (Linnaeus, 1758)

(Figure 2; Table 1)

Sertularia neritina Linnaeus, 1758: 815.

Bugula neritina: Prenant \& Bobin, 1966: 492, Figs 158VII, 159 III, 161 I, II, 162; Ryland \& Hayward,
1977: 162, Fig 78; Hayward \& Ryland, 1998: 220, Fig 68; Ryland et al., 2011: 19 Figs. 1, 2.

Material examined: MMF44785 (23/10/2013, Dry dock inspections), MMF44786 (11/10/2013, Quinta do Lorde), MMF44787 (13/01/2014, Funchal) MMF44967 (17/09/2015, Porto Santo).

\section{Diagnosis}

Erect colony, branching, forming dense tuft until $10 \mathrm{~cm}$ high. Colony brown reddish, sometimes even violet or purple. Biseriate branches, with rectangular boat-shaped autozooids, with almost the entire frontal wall membranous. Autozooids without spines but with the distal margin well marked. Avicularia absent. Big and globular ovicells jointed by a peduncle to the maternal zooid and with oblique orientation.

\section{Remarks}

Bugula neritina is a well-known widespread species, it was first detected for Madeira Island by Norman [29] in 1909 in Funchal, near a coaling ship in natural substrate. It has not been reported elsewhere, up until 2012 where it was found growing on the artificial PVC settling plates

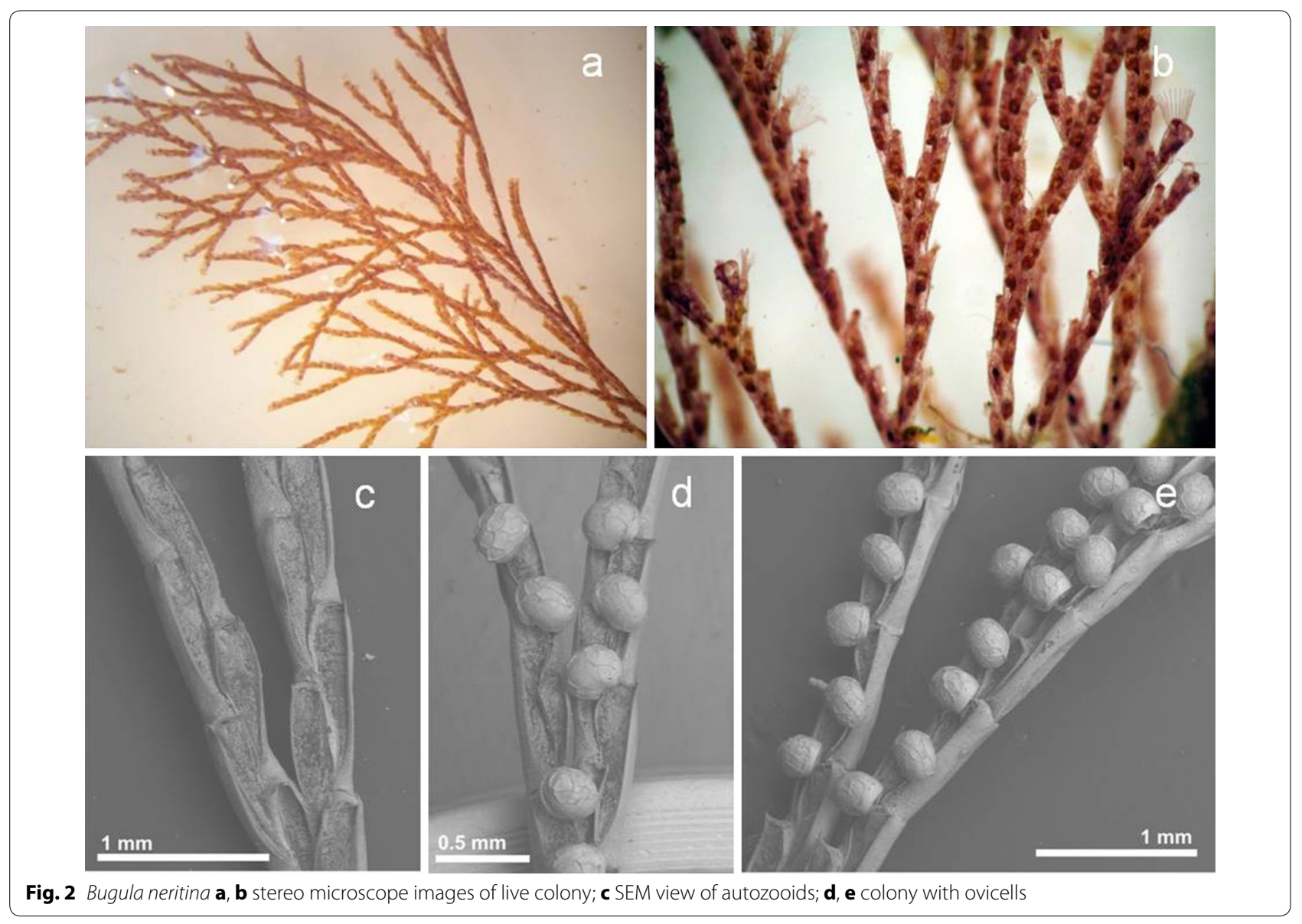


in the marina of Calheta. From 2013 until March 2015, this species was constantly registered in all marinas of the South coast of Madeira and also in Porto Santo Island. In this study, B. neritina is reported here as a first record for the marina of Porto Santo Island (Table 1).

In addition, we have found $B$. neritina present in seven of the nine recreational vessels examined for DDI, in four foreign vessels, and in three domestic vessels from Funchal.

Biogeography status: NIS [50, 58-60]

Genus Bugulina Gray, 1848

Bugulina flabellata (Thompson, in Gray, 1848)

(Figure 3; Table 1)

Avicularia flabellata Thompson, in Gray, 1848: 106.

Bugula flabellata: Hincks, 1880: 80, pl. 11, Figs. 1, 2, 3, 4; Prenant \& Bobin, 1966: 503, Fig 158 X, XI, 160 I, I', 161 III-V, 167; Ryland \& Hayward, 1977: 158, Fig 76; Hayward \& Ryland, 1998: 216, Fig 66.

Bugula calathus minor: Alves and Cocito, 2002: 1, Fig. 1.

Bugulina flabellata: Fehlauer-Ale et al. 2015: 341.

Material examined: MMF44788 (09/08/2013, Calheta) MMF44789 (21/01/2014, Calheta), MMF44790 (15/10/2013, Calheta), MMF44791 (06/02/2015, Funchal), MMF44792 (29/05/2014, Funchal). Other material: MMF31648: Bugula calathus minor (01/07/1998, Funchal harbour).

\section{Description}

Colonies erect, forming dense tufts, light yellow in colour. Branches formed by series of three to eight autozooids in width. Autozooids elongated, rectangular, about $0.612 \mathrm{~mm}(0.499-0.763 \mathrm{~mm}, 19)$ long and about $0.148 \mathrm{~mm}(0.130-0.182 \mathrm{~mm}, 19)$ wide. Frontal membrane occupies almost the entire frontal area. Spines very variable in size along the colony. Three spines in the outer distal corner, the two of them more proximal are directed obliquely or frontally, and the one more distal is directed distally. Two spines in the inner distal corner, both with disto-frontal direction. Pedunculate avicularia positioned in the distal part of the margin of the frontal membrane, below the spines. Avicularia on the outer zooids big in size, about $0.187 \mathrm{~mm}(0.154-0.218 \mathrm{~mm}, 16)$ and smaller in the inner zooids $0.106 \mathrm{~mm}(0.094-0123 \mathrm{~mm}, 11)$. The beak of the avicularia abruptly, almost rectangular, hooked. Globular big ooecia located in the midline of the maternal zooid. Embryos light yellow in colour.

\section{Remarks}

Busk [24] recorded Bugula flabellata var. biseriata s. ditrupae from Madeira, and subsequently the same author [25] identified it as a different species, Bugula ditrupae and later Norman [29] confirmed this record. Both species are easily distinguishable, Bugula ditrupae is formed by biserial branches and in Madeira it was recorded always associated with species of the genus Ditrupa (polichaeta) [29].

Alves and Cocito [36] recorded Bugulina calathus minor from Madeira Island in 1998. Nevertheless, we examined the specimen studied by Alves and Cocito [36] (MMF31648) and it seem co-specific with our material. It presents the beak of the avicularia hooked almost rectangularly, as it happens in our specimens (can also see in Alves and Cocito Fig. 1a, note that it is not possible to see in the Fig. 1b because the position of the avicularia), been the beak of the avicularia smoothly down-curve in B. calathus [e.g. 47, 62]. Beside, in the avicularia of the specimens from Alves and Cocito [36] have the edge from the peduncle to the mandibular proximal border shorter and more curve than in the avicularia of Bugula calathus [e.g. $47,51,62,63]$.

No other records of this species have been detected for Madeira Island until this work; here, we found B. flabellata for the first time for the marina of Calheta in 2013 and 2014, and for the marina of Funchal in 2014 and 2015.

Biogeography status: native $[47,58]$

\section{Bugulina fulva (Ryland, 1960)}

(Figure 4, Table 1)

Bugula fulva Ryland, 1960: 86, Figs 1D, 2H, 10 A, B, Pls. 1D, 2B

Bugula fulva, Prenant \& Bobin, 1966: 511, Figs 158 IX, 160 VI, 171, 172; Ryland \& Hayward, 1977: 160, Fig 77; Hayward \& Ryland, 1998: 218, Fig 67; Vieira et al. 2012: 5, Fig 3E-F.

Bugulina fulva, Fehlauer-Ale et al. 2015: 8.

Material examined: MMF44793 (14/10/2013, Funchal), MMF44794 (01/08/2014, Funchal), MMF44795 (12/03/2014, Dry dock inspections).

\section{Description}

Colony erect, forming dense tufts, but non-spiralling, light yellow to light brown in colour. Branches biserial, turning to quadriserial close to the dichotomies. Autozooids rectangular or slightly narrower in the proximal part, $0.605 \mathrm{~mm}(0494-0.696 \mathrm{~mm}, 22)$ long and $0.148 \mathrm{~mm}$ (0124-0.171 mm, 22) wide. The frontal membrane occupies almost all frontal surface. Three spines in the outer distal margin (only two in ovicellate zooids) and two in the inner margin. Avicularia pedunculate, about $0.136 \mathrm{~mm}(0.102-0.168 \mathrm{~mm}, 22)$ long, attached in the external lateral wall, in the distal half part of the membranous area. In dichotomies can present smaller avicularias 

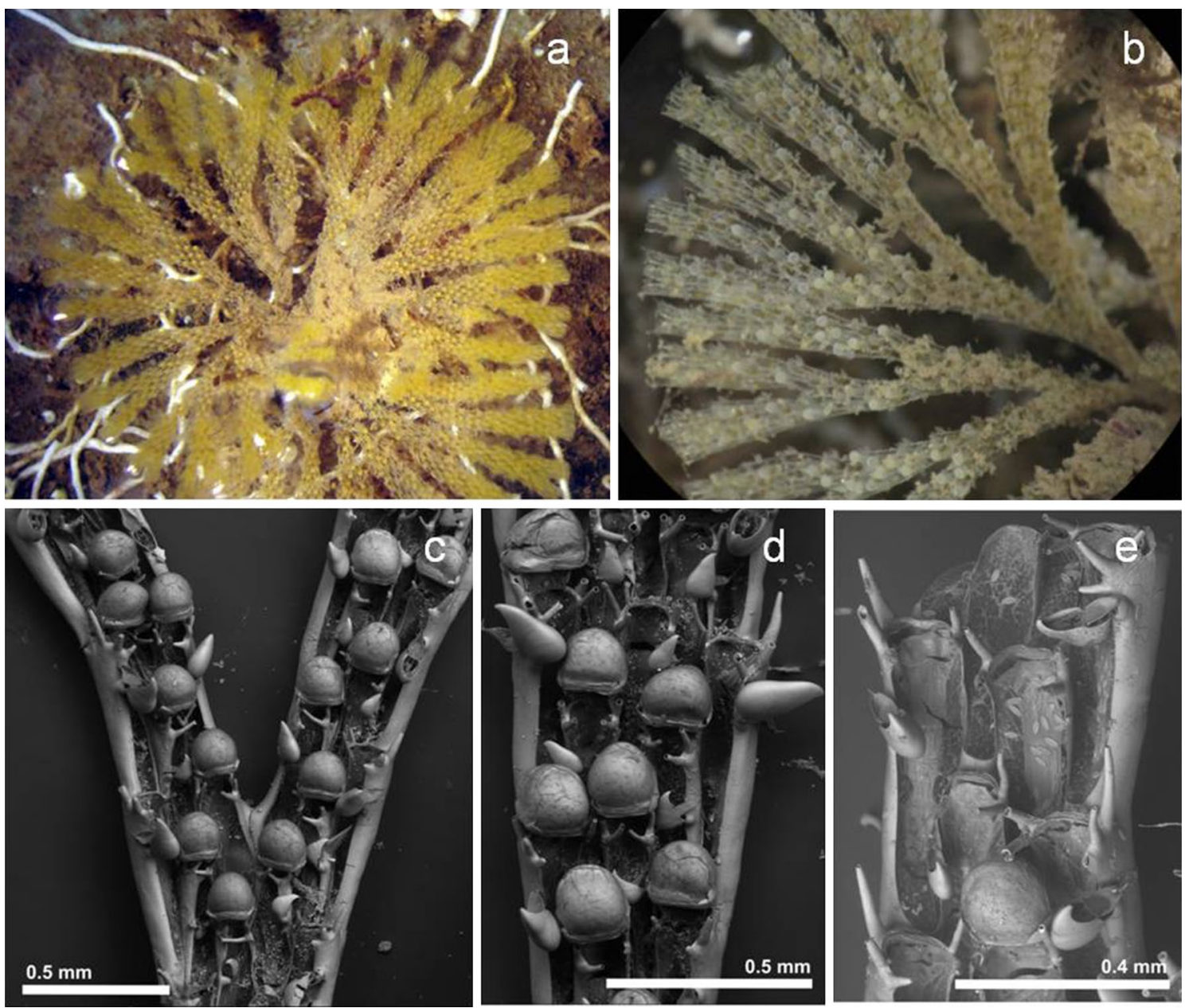

Fig. 3 Bugulina flabellata $\mathbf{a}$, b stereo microscope images of live colony; c frontal view of the branching; $\mathbf{d}$ colony with ovicelled zooids; e growing margin of one colony

in the inner zooids, but few abundant. Avicularia globular, with round body and well development rostrum with the beak down curved. Ooecia subglobular centered in the midline.

\section{Remarks}

To date, Bugulina fulva has never been recorded for both Madeira and Porto Santo Islands. This study represents the first record of this species for Madeira Island with records for the Funchal marina in 2013 and 2014. This species was also found in one local recreational vessel from the Funchal marina and still remains undetected elsewhere in Madeira.

Biogeography status: cryptogenic [57-59]

Bugulina simplex (Hincks, 1886)

(Figure 5, 6; Table 1)
Bugula simplex: Hincks, 1886: 254; Prenant \& Bobin, 1966: 505, Fig 158 VI, 160 II, 161 VII, 168; Ryland \& Hayward, 1977: 168, Fig 81; Hayward \& Ryland, 1998: 226, Fig 71.

Bugulina simplex: Fehlauer-Ale et al. 2015: 6.

Material examined: MMF44796 (17/01/2014, Quinta do Lorde), MMF44797 (30/04/2014, Quinta do Lorde), MMF44798 (30/04/2014, Quinta do Lorde), MMF44799 (26/01/2015, Quinta do Lorde), MMF44800 (11/10/2013, Quinta do Lorde), MMF44801 (13/01/2014, Funchal) MMF44802 (12/03/2014, Dry dock inspections).

\section{Description}

Colony erect, funnel shape, not-spiralling, up to $3 \mathrm{~cm}$ in height, translucent white to yellow in colour. Branches formed by series of two to six autozooids, generally narrow at their origin and broader distally. Autozooids 


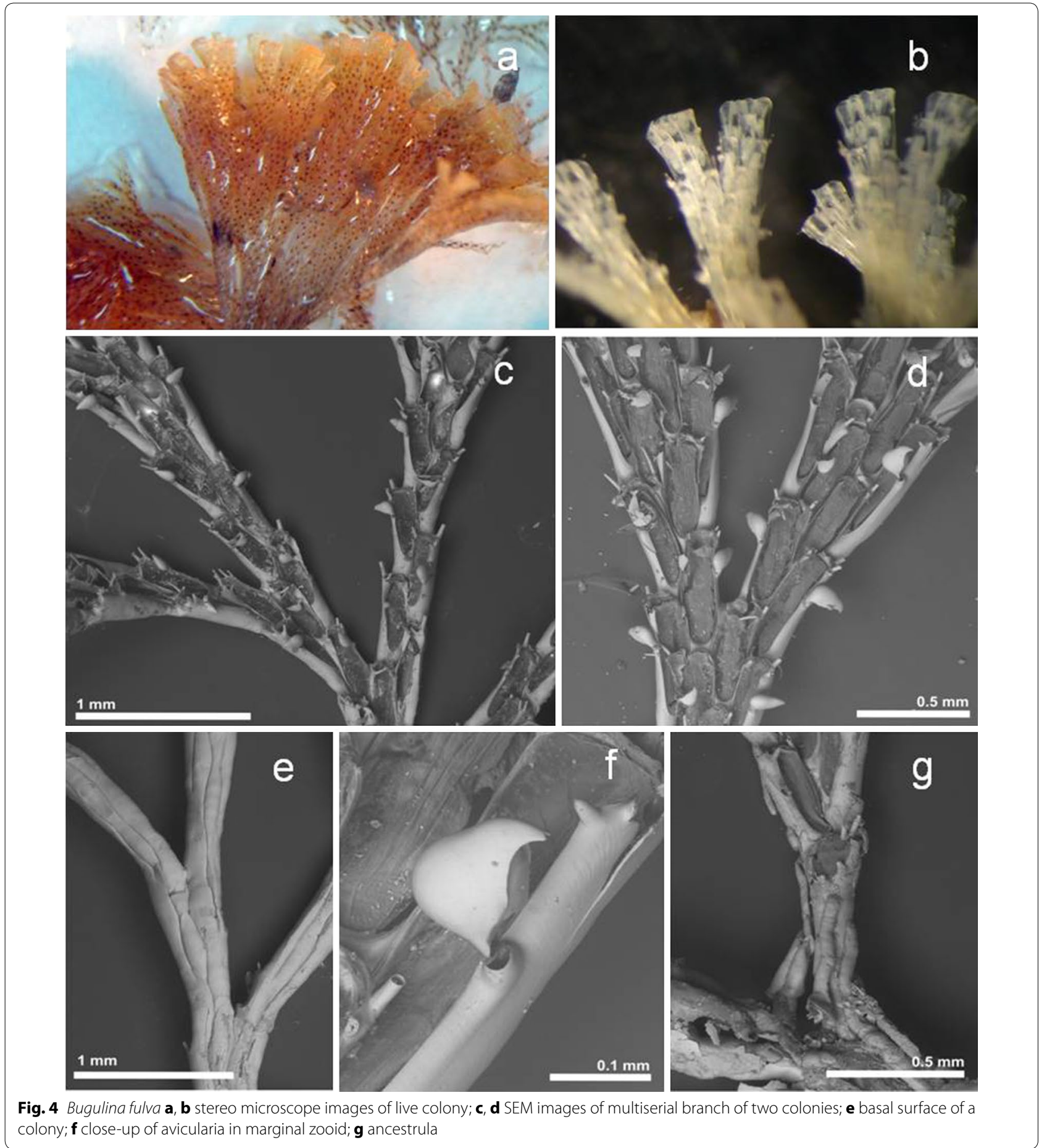

rectangular or lightly wider distally, $0.581 \mathrm{~mm}(0.476-$ $0.698 \mathrm{~mm}, 21)$ long and $0.136 \mathrm{~mm}(0.120-0.157 \mathrm{~mm}$, 21) wide; with the frontal surface almost membranous. Usually one spine in each disto-lateral margin, but occasionally one second short spine is in the outer angle.
Pedunculate avicularia monomorphic, only present in the marginal zooids, disposed in the distal quarter of the margin, below the spine; longer that the wide of autozooides, $0.183 \mathrm{~mm}(0.164-0.209 \mathrm{~mm}, 22)$ long. The beak of the avicularia is down curved. Ooecia hemispherical, 

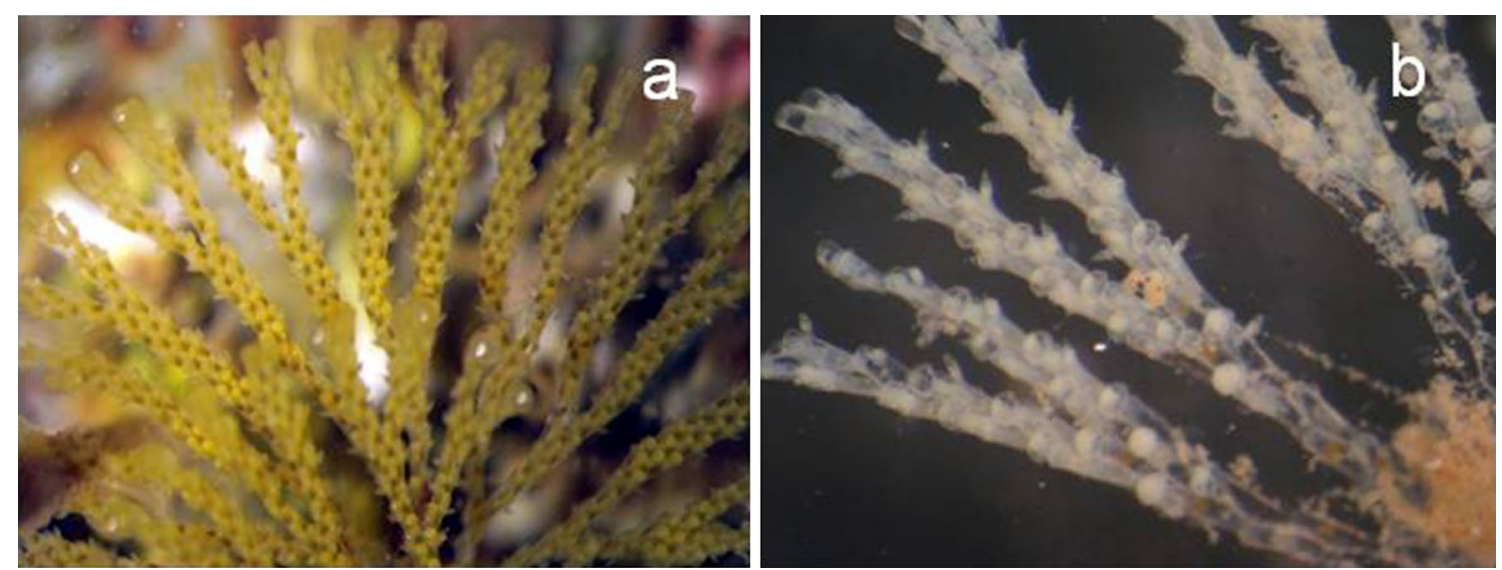

Fig. 5 Bugulina simplex $\mathbf{a}$, b stereo microscope images of live and dead colony, respectively

$0.083 \mathrm{~mm}(0.076-0.098 \mathrm{~mm}, 7)$ long and $0.176 \mathrm{~mm}$ (0.159-0.187 mm, 7) wide; endocist calcified, ectocist membranous, but lateral and a thin frontal area calcified.

\section{Remarks}

This study represents the first record of Bugulina simplex for Madeira, with records in 2013, 2014 and 2015 in the marina of Quinta do Lorde. This species was also detected at the Funchal marina in 2014 and on one local vessel by DDI.

Biogeography status: NIS $[50,58,60]$

\section{Bugulina stolonifera (Ryland 1960)}

(Figure 7; Table 1)

Bugula stolonifera Ryland 1960: 78; Prenant \& Bobin, 1966: 541, Fig 158 XII, 159 II, 187; Ryland \& Hayward, 1977: 170, Fig 82; Hayward \& Ryland 1998: 228, Fig 72.

Bugulina stolonifera: Fehlauer-Ale et al. 2015: 6.

Material examined: MMF44803 (23/10/2013, Dry dock inspections), MMF44804 (01/08/2014, Funchal), MMF44805 (23/10/2013, Dry dock inspections), MMF44806 (23/10/2013, Dry dock inspections), MMF44807 (30/04/2014, Quinta do Lorde).

\section{Description}

Erect colony growing in dense mass but not in spiral development, transparent white in colour. Biserial branching, but not increasing the number of zooid in bifurcations. Autozooids long and slender, $0.595 \mathrm{~mm}$ (0.461-0.675 mm, 18) long and $0.133 \mathrm{~mm}(0.100-$ $0.165 \mathrm{~mm}, 18$ ) wide, lightly narrower in the proximal area of the zooid and lightly longer in the bifurcations. Frontal membrane occupies approximately three quarters of the frontal area, with the proximal margin U-shaped. Two spines in the outer angle, and only one in the inner angle of the autozooid distal margin. These spines can be very reduced in some parts of the colony, forming only a small projection. Pedunculate avicularia monomorphic, globular, $0.140 \mathrm{~mm}(0.097-0.155 \mathrm{~mm}, 25)$ long; with a short down curved rostrum, attached bellow the spines in the outer margin. Ooecia globular, well developed, lightly wider than long, $0.122 \mathrm{~mm}(0.101-0.124 \mathrm{~mm}, 7)$ long and $0.157 \mathrm{~mm}(0.140-0.164 \mathrm{~mm}, 7)$ wide; with the lateral and thin proximal part of the ectoecium calcified.

\section{Remarks}

Bugulina stolonifera was first reported for Madeira in the marina of Quinta do Lorde in 2010 by CanningClode, Fofonoff [17]. In 2014, this species was still present in the same location. Also in 2013, we detected its presence during a DDI in a French origin vessel. In 2014, we recorded the presence of Bugulina stolonifera for the marinas of Funchal and Quinta do Lorde.

Biogeography status: NIS $[17,50,58]$

\section{Genus Crisularia Gray, 1848}

Crisularia gracilis (Busk, 1858)

(Figure 8; Table 1)

Bugula gracilis: Busk, 1858a: 125, Pl. 19, Fig. 1; Ryland, 1963: 537, Fig. 1; Bobin \& Prenant, 1963: 33, Figs. 1, 2, 3, 4; Prenant \& Bobin, 1966: 529, Figs 181, 182.

Crisularia gracilis: Fehlauer-Ale et al. 2015: 9.

Material examined: MMF44808 (16/02/2015, Porto Santo).

\section{Description}

Colony erect, with spiral growing and up to $5 \mathrm{~cm}$ high, yellow pale in colour, with dicotomical branches and 

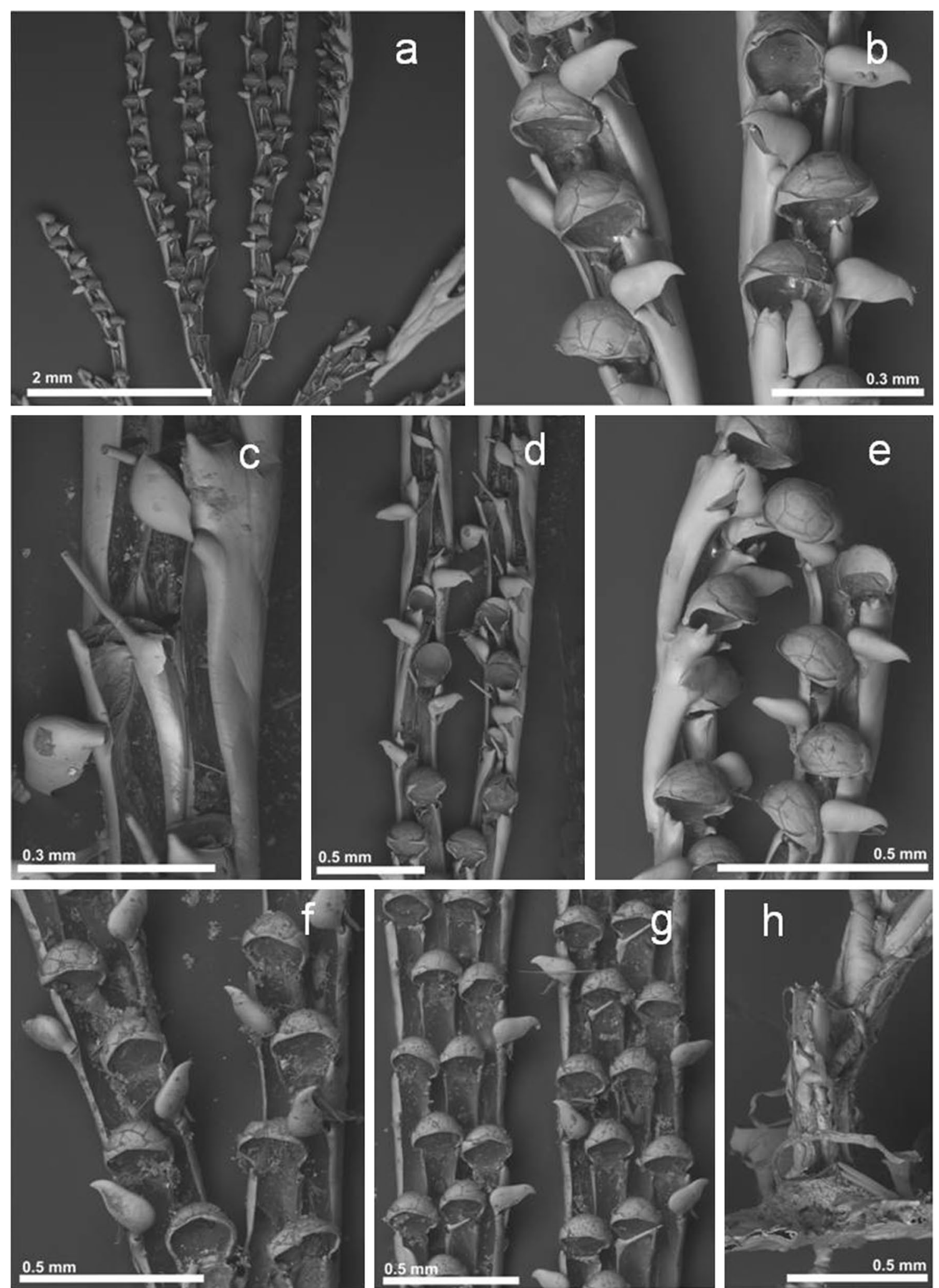

Fig. 6 Bugulina simplex $\mathbf{a}$ SEM view of a colony; $\mathbf{b}-\mathbf{e}$ colonies with different development of spines and ovicells; $\mathbf{f}, \mathbf{g}$ same colony with different multiserial branches development; $\mathbf{h}$ ancestrula 

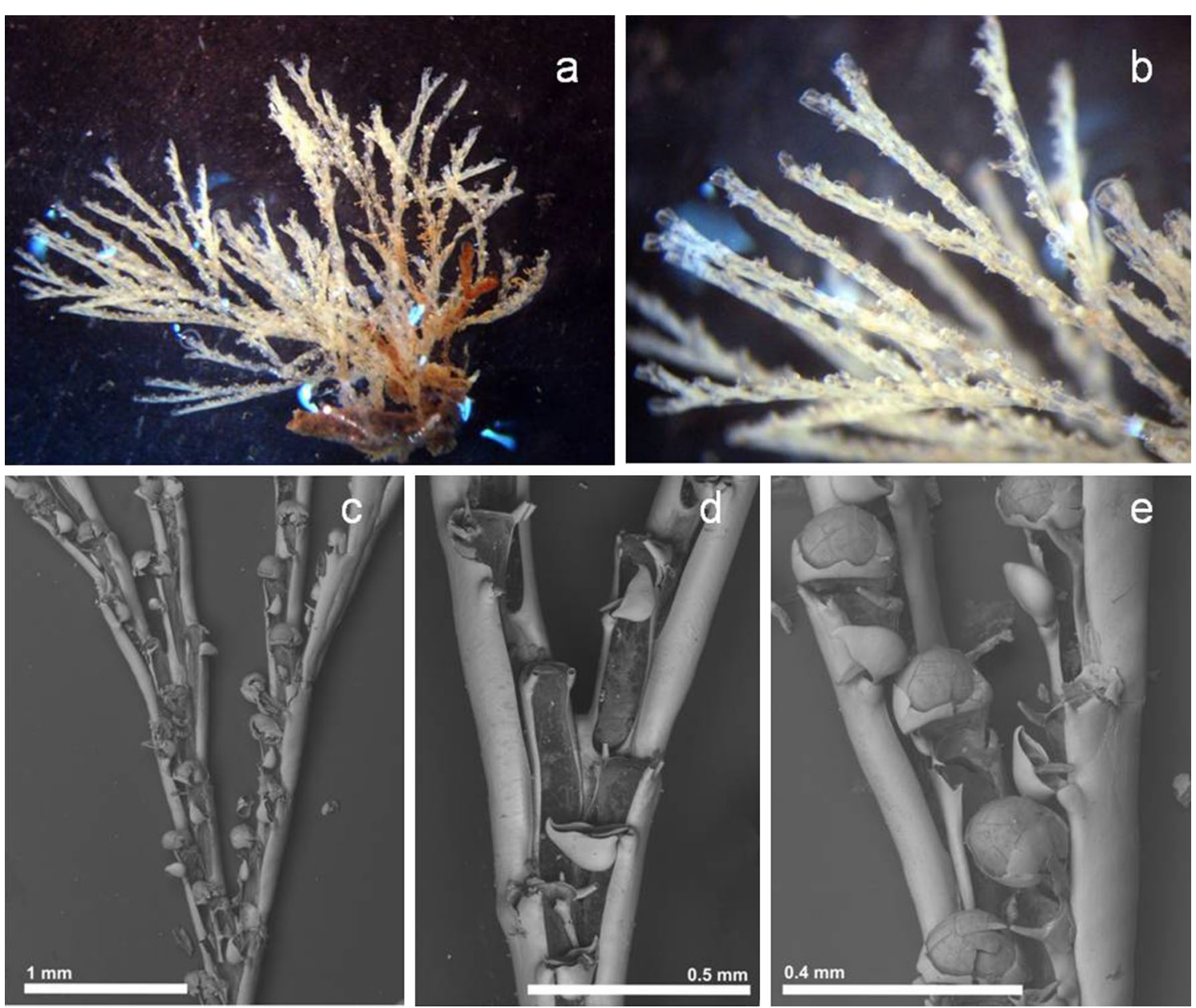

Fig. 7 Bugulina stolonifera $\mathbf{a}$, b stereo microscope images of dead colony; c SEM image of one colony: $\mathbf{d}$ bifurcation; e close-up of ovicelled zooids

bifurcation type 3 (Harmer, 1923). Elongated autozooids, $0.569 \mathrm{~mm}(0.476-0.662 \mathrm{~mm}, 9)$ long and $0.139 \mathrm{~mm}$ (0.105-0.162 mm, 9) wide; the frontal membranous occupies between two-thirds and one half of the frontal area, with a U shaped proximal edge. Outer distal corner has generally a short and slender spine; inner side with a longer spine; and one-third generally longer and slender spine, about $0.230 \mathrm{~mm}(0.177-0.280 \mathrm{~mm}, 6)$, situated in the middle of the distal margin, slightly moved to the outer side. Pedunculate avicularia long, with a well marked indentation between the frontal body surface and the rostrum; and presents the beak steep down curved. The avicularias are few abundant, disposed in the outer margin situated in the medium of the distance of the membranous area. Ooecia globular with only a small distal area calcified.

\section{Remarks}

Crisularia gracilis was first described from Madeira by Busk [24] in 1858, and it is here described for the first time for Porto Santo Island. This specimen was collected in 2015 at one of the pontoons at Porto Santo marina at $0.5 \mathrm{~m}$ depth and not from the PVC panels deployed at the marina. The identity of Crisularia gracilis is confused [see 65] but our specimen seems to coincide with the original and other subsequent descriptions found in the literature [24, 62, 65]. Previous records of this species seem questionable and in some cases have been assigned to other species (see Bugula turrita in Ryland [47]).

Biogeography status: due to the problems in the identification and identity of this species [see 65] and as it was originally described from Madeira [24], we considered it here as a cryptogenic species, however additional work will be necessary to clarify the status of this species.

Genus Virididentula Fehlauer et al. 2015

Virididentula dentata (Lamouroux, 1816)

(Figure 9; Table 1) 

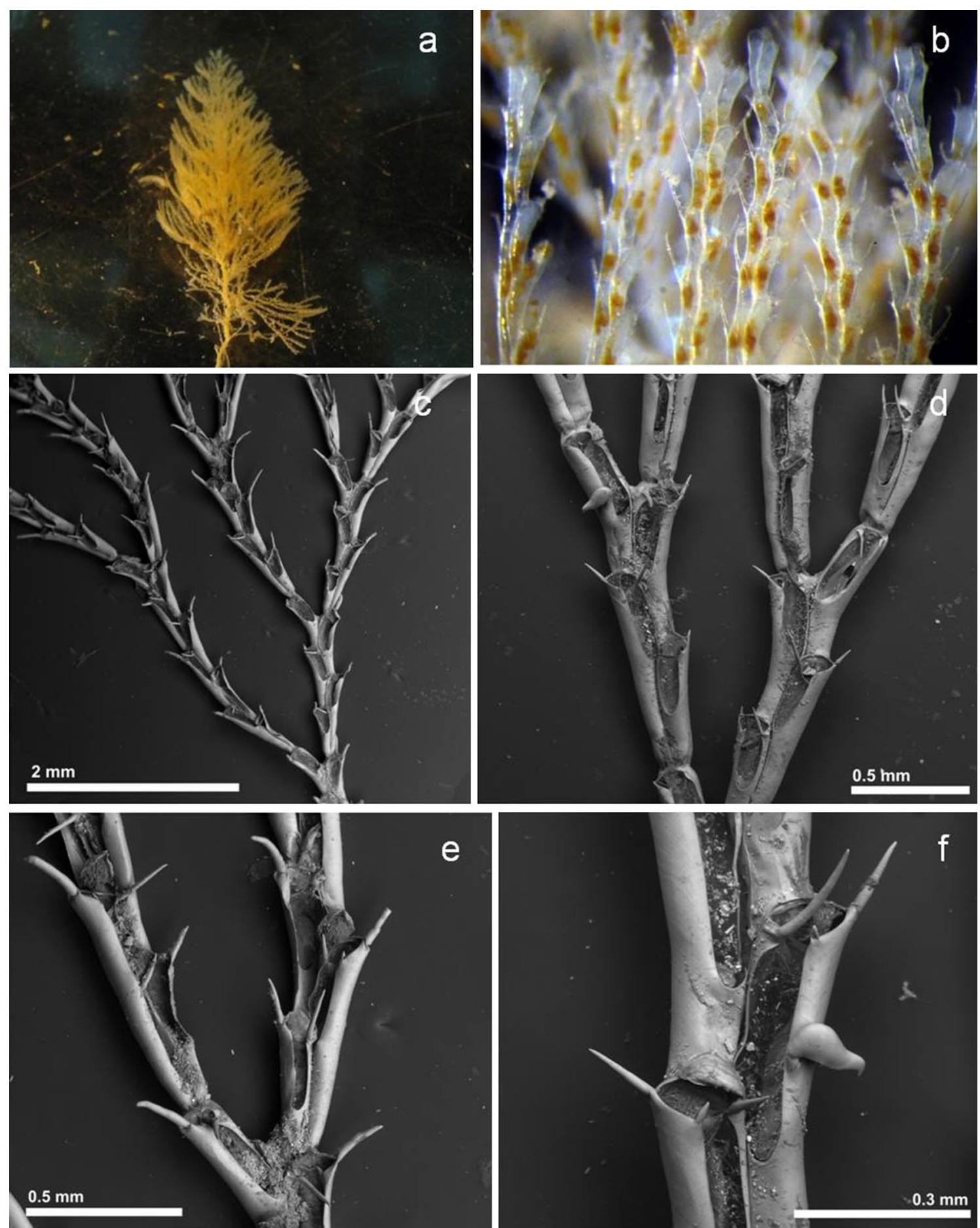

Fig. 8 Crisularia gracilis $\mathbf{a}$, b stereo microscope images of live colony; $\mathbf{c}$ SEM image of the colony: $\mathbf{d}$ branches with one avicularia; $\mathbf{e}$ part of the colony with ovicells; $\mathbf{f}$ close-up of zooid with avicularia 
Acamarchis dentata Lamouroux, 1816: 135, Pl. 3, Figs. 3a, b.

Bugula dentata: Busk, 1852: 46, Pl35, Figs. 1, 2, 3, 4, 5; Norman, 1909: 285, Pl. 36, Fig. 3; Florence et al. 2007: 17, Figs. 5E-F, 20B, 21L.

Virididentula dentata: Fehlauer et al. 2015: 9, Fig. S4. Material examined: MMF44809 (27/05/2014, Quinta do Lorde), MMF44810 (16/02/2015, Porto Santo), MMF44811 (23/10/2013, Porto Santo) MMF44812 (05/08/2013, Quinta do Lorde).

\section{Description}

Erect colony, forming branching tufts, with greenishgrey colour. Zooids dispose in biserial disposition along the branches, including in the dichotomies, where the number of zooids is not increasing. Rectangular and elongated zooid, about $0.541 \mathrm{~mm}(0473-0.594 \mathrm{~mm}, 10)$ long and $0.184 \mathrm{~mm}(0.164-0.210 \mathrm{~mm}, 10)$ wide; lightly narrower proximally. The frontal membrane occupies between two-thirds or three quarters of the frontal area, about $0.357 \mathrm{~mm}(0.316-0.395 \mathrm{~mm}, 10)$ long and $0.144 \mathrm{~mm}(0.111-0.164 \mathrm{~mm}, 10)$ wide; with a narrow U-shaped proximal edge. Three articulate spines over the outer distal margin and one in the inner margin. Pedunculate avicularia situated to the level of the proximal third of the frontal membrane; elongated, about $0.182 \mathrm{~mm}$ $(0.160-0.199 \mathrm{~mm}, 14)$ long; with a long rostrum with the beak hooked rectangularly and with the distal and central margin pointed. Ooecia globular, directed obliquely inwards.

\section{Remarks}

This species was recorded for the first time in Madeiran waters by Norman [29] in 1909, in Porto Santo Island. More than a century later, Canning-Clode, Fofonoff [17] have detected Virididentula dentata (as Bugula dentata) for Madeira Island in Quinta do Lorde marina in 2007, 2010 and 2012. Since then, it has been detected in both Quinta do Lorde and Porto Santo marinas in 2013, 2014 and 2015.

Biogeography status: NIS [17]

\section{Discussion}

Bryozoans represent a group of colonial invertebrates in benthic ecosystems and can be commonly found in fouling assemblages [66, 67]. The transportation of fouling communities in ship hulls is considered a significant and ancient vector for the introduction of non-indigenous species at a global scale $[68,69]$. Like other fouling communities representatives (e.g. barnacles, mussels) bryozoans seem to present life forms that make survival in ship hulls possible [70].
Bugula neritina is a widely known cosmopolitan bryozoan species since the eighteenth century [71], distributed in warm-temperature and subtropical coastal waters, known as an important component of the fouling communities colonizing artificial substrates (see historical review in Ryland, Bishop [50]). This species is able to attach to ship hulls [41] showing tolerance to heavy metals, such as copper and zinc present in several antifouling paints $[55,72]$. Bugula neritina is currently considered a species complex forming at least three different lineages (Type $S$, $\mathrm{D}$ and $\mathrm{N}$ ) that also differ in their distributional patterns $[49,71,73,74]$. Type $S$ is the most widely distributed, appearing in tropical, subtropical and temperate waters around the world, including the North-eastern Atlantic $[49,50,71]$. Type D has a more restricted distribution, probably endemic to California $[71,73]$ while Type $\mathrm{N}$ was initially found only in the North-western Atlantic [74] but latter Fehlauer-Ale, Mackie [71] found this type in Townsville (Coral Sea) and Central California, what could indicate a recent expansion. In this context, we presume the specimens of $B$. neritina found in Madeiran waters belong to type $S$, but we emphasize the need for future molecular studies to confirm this assumption.

Linnaeus [45] described this species for the Mediterranean and the American seas, but the true origin of $B$. neritina remains unknown. According to the dispersal capacity of a sessile species with a lecitotrophic larva [75, 76] it is not expected the actual distribution of Type $S$ for natural dispersion. Several haplotypes were discovered with a long distribution of the Type $S$, with supported correlation with sea surface temperature (for more details see Fehlauer-Ale, Mackie [71]). The study of these different haplotypes allow some latitude in speculating about the possibility of two different origins of Type $S$ for $B$. neritina, the North-eastern Pacific (California) or Southwestern Atlantic (Brazil) [71].

In Madeira, Bugula neritina was first recorded by Norman [29] in Funchal, near the coaling ship inside the port area which today no longer exists, since it was destroyed in the late 1960s. Surprisingly, until recently it has not been reported elsewhere for Madeira, perhaps due to a low sampling effort over the years. However, since we initiated our surveys for NIS diversity in local marinas, B. neritina was detected on artificial PVC plates in the Calheta marina in 2012. Moreover, from 2013 to 2015 B. neritina was always found present in all four marinas of the Madeira archipelago, including a first record for the Porto Santo marina in 2013. It is not possible to determine since when $B$. neritina has been present in Porto Santo Island, but we suspect this species has been likely introduced to both Madeira and Porto Santo via hull fouling. Bugula neritina is considered here as NIS [50, 

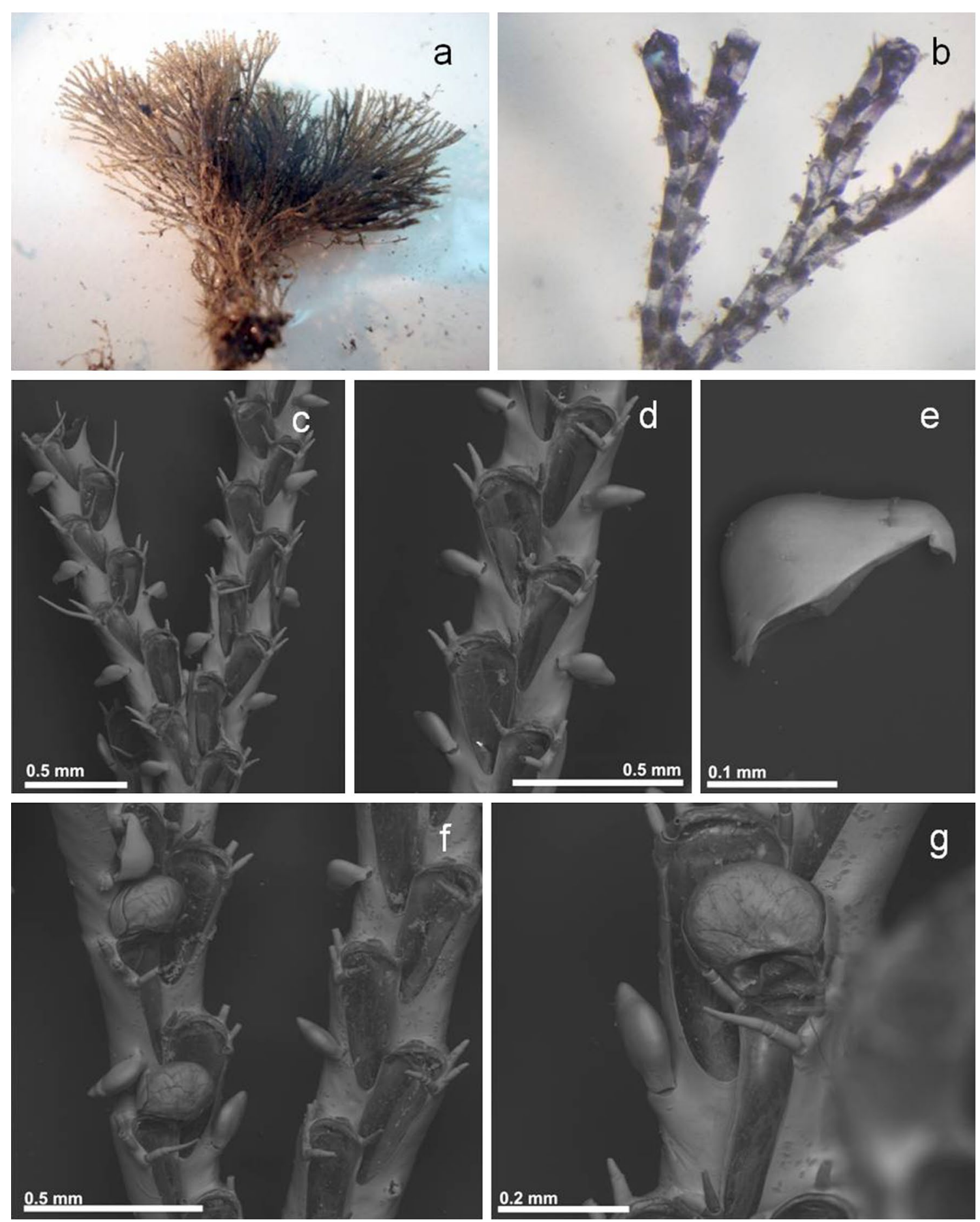

Fig. 9 Virididentula dentata $\mathbf{a}, \mathbf{b}$ stereo microscope images of dead and live colony, respectively; $\mathbf{c}$ SEM image of the colony: $\mathbf{d}$ biserial branches; $\mathbf{e}$ close-up of avicularia; $\mathbf{f}, \mathbf{g}$ close-up of ovicelled zooids

58-60]. Our data from dry dock inspections indicate a significant prevalence in the hull of recreational vessels, as it was found present in four foreign vessels and three local recreational vessels from Funchal.
Bugulina flabellata is considered native and widely distributed in the Western Europe [50], and was also recorded in the Mediterranean [77] and Adriatic seas [78]. Bugulina flabellata was recently documented as 
introduced in Australia and New Zealand, presumably having travelled on ships [50, 79]. In this study, we re-examined the material collected by Alves and Cocito [36] and have corrected its identification to B. flabellata instead of Bugulina calathus minor, since it is co-specific with our sampled material. This is still the first record for Madeira Island which was collected from Funchal harbour in 1998 by Alves and Cocito [36]. Since then, we detected B. flabellata in 2013 and 2014 for the marina of Calheta and yet again, for the marina of Funchal in 2014 and 2015. Given its broad distribution in European waters, we considered it as being native in Madeira [47, 58].

Bugulina fulva was first described from the England Coast [47] occurring in natural (holdfast of Laminaria and boulders) and artificial substrates, appearing during summer in England and Wales [63, 80]. After being described, Bugulina fulva was recorded from different parts of the world. Maturo [81] found this species at the South coast of the USA of America always on natural substrates. Nevertheless, this species is characterized to appear as a fouling component on artificial substrates: was found from the tropical west coast of Africa in the Luanda harbour (Angola) by Cook [82]; in the western Mediterranean by Zabala [83]; and in the Adriatic [see 78]. Also, [84, 85] found this species in Belgian waters colonizing plastic debris. Ronowicz, Kukliński [80] found this species as a component fouling assemblages during summer settlement experiments. Hayward and Ryland [63] also recorded this species in the West Atlantic coast from Maine to Brazil. However, no previous records were found for this species in Madeira Island. According to the general distribution of this species, we also believe it could reflect a recent introduction for the Madeira region and is assigned here as cryptogenic [57-59].

Bugulina simplex is well known from settlement panels used for fouling studies in Britain, but was never found on natural substrates by dredging [47]. In the USA (Woods Hole, Massachusetts), it was found mainly on pier piles and other submerged structures [86], and only rarely colonizing macroalgae. Nevertheless, [87] found B. simplex to be abundant on communities of Zostera marina at 1-6 m depth and in the aquaculture areas of oysters, present both on oysters and on the cages in the Mediterranean. Bugulina simplex has been characterized as a fouling species [47] and recognized as NIS worldwide [50]. Bugulina simplex appears to have a Mediterranean origin [50] and its presence in Madeiran waters is probably a result of a recent introduction and assigned here as NIS [50, 58, 60].

Bugulina stolonifera was first described by Ryland in 1960 from England, mainly found colonizing pier pilings and hull vessels [47]. Cohen and Carlton [88] considered this bryozoan as probably being native to the Northwest Atlantic. In Ryland, Bishop [50] Bugulina stolonifera is recognized as invasive worldwide. Bugulina stolonifera was first described and assigned for Madeiran waters in 2010 as NIS $[17,50,58]$.

Finally, a new genus was recently introduced into the bryozoan literature to accommodate the species Virididentula dentata [42], based on molecular analysis and its peculiar morphological characters. This species was described by Lamouroux [46] from Australasia, and latter different records were confirmed in other regions such as Australia and New Zealand [e.g. 89, 90], South Africa to Cape Verde [e.g. 91-93], Hawaii [48], and Brazil [94]. This broad distribution; the intraspecific morphological variation, mainly related with the zooidal position morphology of the avicularia (no giant avicularias were observed in our specimens); and the orientation of the ooecia [42, $48,90]$ could be indicative of a species complex $[42,48]$. Some authors consider the Indo-Pacific as the origin of this species [17, 95], but other authors described it as a cryptogenic species $[94,96]$. For the Madeira region $V$. dentata is assigned as NIS [17].

Crisularia gracilis was first described from Madeira by Busk [24] in 1858, and is here described for the first time for Porto Santo Island in 2015. Given its original description locality [24] and the lack of more studies we considered Crisularia gracilis as being a cryptogenic species.

Prior to 2012, eight Bugulidae species were recorded for the Madeira Archipelago. During our surveys conducted in the four marinas (Calheta, Funchal, Quinta do Lorde and Porto Santo), we found no evidences for the occurrence of three of these species: Bugulina avicularia, Bugulina ditrupae, and C. plumosa. However, we cannot exclude the possibility of their occurrence in other artificial or even natural substrates, inside or outside marinas and harbours in Madeiran waters. Furthermore, we cannot exclude the possibility of mis-assigned species from earlier records, as it was seen here for Bugulina flabellata as Bugulina calathus minor. Unfortunately, it was not possible to confirm the identity of previously collected specimens of Bugulina avicularia, Bugulina ditrupae, and C. plumosa (and found in our literature survey) as these are not easily accessible, and therefore we suggest additional studies to confirm the identity of these species. Nevertheless, we attributed a native status to Bugulina ditrupae, originally described from Madeira by Busk [24], while Bugulina avicularia and C. plumosa were considered cryptogenic [29].

The present paper represents therefore a key contribution to the current understanding of bryozoan species of the Madeira Islands, regarding Bugulidae. The Madeira archipelago has now registered a total of ten Bugulidae species, with three species present both in 
Madeira and Porto Santo (B. neritina, C. gracilis and V. dentata), six exclusively found in the Madeira Island ( $B$. avicularia, $B$. ditrupae, $B$. flabellata, B. fulva, B. simplex, and B. stolonifera), and one exclusively found in the Porto Santo Island (C. plumosa). Our preliminary findings on dry dock inspections on local and foreign recreational vessels, support the hypothesis from other studies, that emphasize hull fouling as a key introduction vector that contributes to the arrival and spread of NIS to neighbouring regions. Thus, we strongly believe that all non-indigenous species of Bugulidae reported here for the Madeira archipelago were introduced via hull fouling.

\section{Authors' contributions}

PR executed the study, attain the specimens' samples with stereo microscope images and wrote the manuscript. JS analysed, described and measured all specimens' samples with SEM images and wrote the taxonomic part of the manuscript. JCC conceived the study, participated in its design, coordination and helped to write and revise the manuscript. All authors read and approved the final manuscript.

\section{Author details}

${ }^{1}$ MARE - Marine and Environmental Sciences Centre, Estação de Biologia Marinha do Funchal, Cais do Carvão, 9000-107 Funchal, Madeira, Portugal. ${ }^{2}$ Institut für Paläontologie, Geozentrum, Universität Wien, Althanstrasse 14, 1090 Vienna, Austria. ${ }^{3}$ Departamento de Zoología y Antropología Física, Universidad de Santiago de Compostela, 15782 Santiago de Compostela, Spain. ${ }^{4}$ Department of Oceanography and Fisheries, Centre of IMAR of the University of the Azores, Rua Prof. Dr. Frederico Machado, 4, 9901-862 Horta, Azores, Portugal. ${ }^{5}$ Smithsonian Environmental Research Center, 647 Contees Wharf Road, Edgewater, MD 21037, USA.

\section{Acknowledgements}

We thank Porto Santo Line for their travel aid to the Island of Porto Santo and the administration of the four marinas used for this study (Porto Recreio da Calheta, Marina do Funchal, Marina da Quinta do Lorde (Caniçal) and Marina do Porto Santo). P. Ramalhosa was partially funded by the Project Observatório Oceânico da Madeira-OOM (M1420-01-0145-FEDER-000001), co-financed by the Madeira Regional Operational Programme (Madeira 14-20), under the Portugal 2020 strategy, through the European Regional Development Fund (ERDF). J. Canning-Clode was supported by a starting grant in the framework of the 2014 FCT Investigator Programme (IF/01606/2014/CP1230/CT0001). The work of J. Souto was supported by the Austrian Science Fund (FWF, Lise Meitner Program, Grant M1444-B25). This is contribution number 31 of Marine Biology Station of Funchal. We are thankful to three anonymous reviewers which provided helpful comments and suggestions that improved substantially this manuscript.

Received: 24 November 2015 Accepted: 9 May 2016

Published online: 10 June 2016

\section{References}

1. Bax N, et al. Marine invasive alien species: a threat to global biodiversity. Mar Policy. 2003;27(4):313-23.

2. Olenin $\mathrm{S}$, et al. Recommendations on methods for the detection and control of biological pollution in marine coastal waters. Mar Pollut Bull. 2011;62(12):2598-604.

3. Clarke Murray C, et al. Spatial distribution of marine invasive species: environmental, demographic and vector drivers. Divers Distrib. 2014;20:824-36.

4. Minchin D, Gollasch S. Fouling and ships' hulls: how changing circumstances and spawning events may result in the spread of exotic species. Biofouling. 2003;19(S1):111-22.
5. Ruiz GM, et al. Invasion of coastal marine communities in North America: apparent patterns, processes, and biases. Ann Rev Ecol Syst. 2000;31:481-31.

6. Carlton JT, Geller JB. Ecological roulette: the global transport of nonindigenous marine organisms. Chem Phys Lett. 1991;179:53.

7. Arenas F, et al. Alien species and other notable records from a rapid assessment survey of marinas on the south coast of England. J Mar Biol Assoc UK. 2006;86(06):1329-37.

8. Wonham MJ, Carlton JT. Trends in marine biological invasions at local and regional scales: the Northeast Pacific Ocean as a model system. Biol Invasions. 2005;7(3):369-92.

9. Glasby TM, et al. Nonindigenous biota on artificial structures: could habitat creation facilitate biological invasions? Mar Biol. 2007;151(3):887-95.

10. Marchini A, Ferrario J, Minchin D. Marinas may act as hubs for the spread of the pseudo-indigenous bryozoan Amathia verticillata (Delle Chiaje, 1822) and its associates. Sci. Mar. 2015;79(3):355-65.

11. Cohen A, et al. Rapid assessment survey for exotic organisms in southern California bays and harbors, and abundance in port and non-port areas. Biol Invasions. 2005;7(6):995-1002.

12. Cohen A, et al. A rapid assessment survey of non-indigenous species in the shallow waters of Puget Sound. Report of the Puget sound expedition. Prepared for the Washington State Department of Natural Resources, Olympia, WA; 1998.

13. Minchin D. Rapid assessment of the bryozoan, Zoobotryon verticillatum (Delle Chiaje, 1822) in marinas, Canary Islands. Mar Pollut Bull. 2012:64(10):2146-50.

14. APRAM, Administração dos Portos da Região Autónoma da Madeira, SA 2016. http://www.portosdamadeira.com/site/index.php/en/. Accessed 23 Feb 2016.

15. Wirtz P, Canning-Clode J. The invasive bryozoan Zoobotryon verticillatum has arrived at Madeira Island. Aquat Invasions. 2009;4(4):669-70.

16. Ramalhosa P, et al. First record of Branchiomma bairdi Mclntosh, 1885 (Annelida: Sabellidae) from Madeiran Island, Portugal (northeastern Atlantic Ocean). Biolnvasions Rec. 2014;3(4):235-9.

17. Canning-Clode J, et al. Marine invasions on a subtropical island: fouling studies and new records in a recent marina on Madeira Island (Eastern Atlantic Ocean). Aquat Invasions. 2013;8:1-10.

18. Ramalhosa P, Canning-Clode J. The invasive caprellid Caprella scaura Templeton, 1836 (Crustacea: Amphipoda: Caprellidae) arrives on Madeira Island, Portugal. Biolnvasions Rec. 2015;4(2):97-102.

19. Souto J, Kaufmann MJ, Canning-Clode J. New species and new records of bryozoans from shallow waters of Madeira Island. Zootaxa. 2015;3925(4):581-93.

20. Appeltans $W$, et al. The magnitude of global marine species diversity. Curr Biol. 2012;22(23):2189-202.

21. Bock PE, Gordon DP. Phylum Bryozoa Ehrenberg, 1831. In: Zhang, Z.-Q. (Ed.) Animal biodiversity: an outline of higher-level classification and survey of taxonomic richness (Addenda 2013). Zootaxa. 2013;3703(1):67-74.

22. Gordon DP. New bryozoan taxa from a new marine conservation area in New Zealand, with a checklist of Bryozoa from Greater Cook Strait. Zootaxa. 2009;1987:39-60.

23. Woollacott RM, Zimmer RL. Biology of bryozoans. Amsterdam: Elsevier; 2013.

24. Busk G. Zoophytology. On some Madeiran Polyzoa. Q J Micropical Sci. 1858;6:124-30.

25. Zoophytology Busk G. On some Madeiran Polyzoa. Q J Micropical Sci. 1858;6:261-3.

26. Busk G. Zoophytology. Q J Micropical Sci. 1859;7:65-8.

27. Busk G. Zoophytology. Q J Micropical Sci. 1860;8:280-5.

28. Busk G. Zoophytology. Q J Micropical Sci. 1861;1:77-80.

29. Norman AM. The Polyzoa of Madeira and neighbouring islands. J Linn Soc Lond. 1909;30:275-314.

30. Waters AW. Bryozoa from Madeira. J R Microsc Soc. 1899;19(1):6-16.

31. Johnson JY. New Cyclostomatous Bryozoa found at Madeira. Ann Mag Nat Hist. 1897;20(6):60-5.

32. Hincks T. Contributions towards a general history of the marine Polyzoa. Part I. Madeiran Polyzoa. Ann Mag Nat Hist. 1880;5(6):69-80.

33. Berning B, Kuklinski P. North-east Atlantic and Mediterranean species of the genus Buffonellaria (Bryozoa, Cheilostomata): implications for biodiversity and biogeography. Zool J Linn Soc. 2008;152(3):537-66. 
34. Berning B, Tilbrook KJ, Rosso A. Revision of the north-eastern Atlantic and Mediterranean species of the genera Herentia and Therenia (Bryozoa: Cheilostomata). J Nat Hist. 2008;42(21-22):1509-47.

35. d'Hondt J-L. Bryozoaires et brachiopodes = Bryozoa and brachiopods Mémoires du Muséum national d'Histoire naturelle. Série A, Zoologie, 1981. 91.

36. Alves F, Cocito S. A new bryozoan record (Bugula calathus minor) for the marine fauna of Madeira Island (NE Atlantic). BOCAGIANA Museu de História Nacional do Funchal. 2002;204:1-5.

37. Souto J, Reverter-Gil O, Ostrovsky AN. New species of Bryozoa from Madeira associated with rhodoliths. Zootaxa. 2014:3795(2):135-51.

38. Berning B. Taxonomic notes on some Cheilostomata (Bryozoa) from Madeira. Zootaxa. 2012;3236:36-54.

39. Bock P. Bugula Oken, 1815, in World List of Bryozoa. Accessed through: World Register of Marine Species at http://www.marinespecies.org/aphia. php? $\mathrm{p}=$ taxdetails\&id =110839 on 23 February 2016, P.G. Bock, D. (2015) Editor. 2015.

40. Vieira LM, Winston JE, Fehlauer-Ale KH. Nine new species of Bugula Oken (Bryozoa: Cheilostomata) in Brazilian shallow waters. PLoS ONE. 2012;7(7):e40492.

41. Winston JE, Woollacott RM. Redescription and revision of some redpigmented Bugula species. Bull Mus Comp Zool. 2008;159(3):179-212.

42. Fehlauer-Ale KH, et al. Identifying monophyletic groups within Bugula sensu lato (Bryozoa, Buguloidea). Zool Scr. 2015;44(3):334-47.

43. Hayward PJ. The Cheilostomata (Bryozoa) of the deep sea. Galathea Rep. 1981;15:21-68.

44. Gray JE. List of the specimens of British animals in the collections of the British Museum. Part 1 Centroniae or radiated animals. London: Trustees of the British Museum (Natural History); 1848.

45. Linnaeus $C$. Systemae naturae per regna tria naturae, secundum classes, ordines, genera, species, cum characteribus, differentiis, synonyms, locis Ed. 10. pp. 1-824. 1758.

46. Lamouroux JV. Histoire des polypiers coralligenes flexibles. A. Caen, De I'Imprimerie de F. Poisson, rue Froide; 1816.

47. Ryland JS. The British species of Bugula (Polyzoa). Proc Zool Soc Lond 1960;134:65-104.

48. Mackie JA, et al. Mitochondrial evidence of geographical isolation in Bugula dentata Lamouroux. Bryozoan Studies 2001, ed. P.N. In: Wyse Jackson, Buttler, C.J. \& Spencer-Jones, M. (editors). 2002: A.A. Balkema Publishers, Lisse, Abingdon, Exton, Tokyo.

49. Mackie JA, Keough MJ, Christidis L. Invasion patterns inferred from cytochrome oxidase I sequences in three bryozoans, Bugula neritina, Watersipora subtorquata, and Watersipora arcuata. Mar Biol. 2006;149(2):285-95.

50. Ryland JS, et al. Alien species of Bugula (Bryozoa) along the Atlantic coasts of Europe. Aquat Invasions. 2011;6(1):17-31.

51. Ryland JS. Some species of Bugula (Bryozoa) from the Bay of Naples. Pubblicazioni Della Stazione Zoologica di Napoli. 1962;33:20-31.

52. Pallas PS. Elenchus Zoophytorum Sistens Generum Adumbrationes Generaliores et Speciarum Cognitarum Succintas Descriptiones cum Selectis Aucttorus Symonymis. Hagae_Comitu van Cleef, Varrentrapp; 1766.

53. Hincks T. The Polyzoa of the Adriatic: a Supplement to Prof. Heller's "Die Bryozoen des adriatischen Meeres,1867. Ann Mag Nat Hist Ser 5. 1886;17(99):254-71

54. Canning-Clode J, et al. Local-regional richness relationship in fouling assemblages-effects of succession. Basic Appl Ecol. 2009;10(8):745-53.

55. Canning-Clode J, et al. The effects of copper pollution on fouling assemblage diversity: a tropical-temperate comparison. PLOS ONE. 2011;6(3):e18026.

56. Schneider CA, Rasband WS, Eliceiri KW. NIH Image to ImageJ: 25 years of image analysis. Nat Methods. 2012;9(7):671-5.

57. AquaNIS, Editorial board information system on aquatic non-indigenous and cryptogenic species. World Wide Web electronic publication. 2015. www.corpi.ku.lt/databases/aquanis. Version $2.36+$. Accessed 13 Nov 2015

58. Fofonoff $P$, et al. National exotic marine and estuarine species information system (NEMESIS). 2014. http://invasions.si.edu/nemesis/. Accessed 13 Nov 2015

59. Katsanevakis S, et al. Building the European Alien Species Information Network (EASIN): a novel approach for the exploration of distributed alien species data. Biolnvasions Rec. 2012;1(4):235-45.
60. Pagad S, et al. World register of introduced marine species (WRIMS). http://www.marinespecies.org/introduced on 2015-11-13 Parry G.D., Currie D.R., Crookes D.P. (1997). Exotic marine pests in Portland Harbour and environs. Mar Freshw Res Inst, Tech Rep 1:1-20. 2015.

61. Ryland JS, Hayward PJ. British anascan bryozoans. London: Academic Press for the Linnaean Society; 1977. p. 1-188.

62. Prenant M, Bobin G. Bryozoaires, Deuxième partie. Chilostomes Anasca. Faune de France. 1966;68:1-647.

63. Hayward PJ, Ryland JS. Cheilostomatous Bryozoa, Part 1, Aeteoidea-Cribrilinoidea. In: RSK Barnes, JH Crothers, editors. Synopses of the British Fauna (new series), No 10, 2nd Edn. Shrewsbury: Field Studies Council; 1998. pp. 1-366.

64. Ryland J. Notes on marine Polyzoa, II. Bugula gracilis Busk. J Nat Hist. 1963;6(69):537-9.

65. Bobin G, Prenant M. Bugula gracilis Busk. Remarques sur la valeur spécifique de l'ovicelle chez les bugules (Bryozoaires Chilostomes). Cah Biol Mar. 1963:4:33-46.

66. Railkin Al. Marine biofouling: colonization processes and defenses. Boca Raton, Florida: CRC Press; 2003.

67. Dürr S, Watson DI. Biofouling and antifouling in aquaculture. In: Dürr S, Thomason JC, editors. Biofouling. Oxford: Wiley-Blackwell; 2009. p. 267-87.

68. Carlton J, Hodder J. Biogeography and dispersal of coastal marine organisms: experimental studies on a replica of a 16th-century sailing vessel. Mar Biol. 1995;121(4):721-30.

69. Gollasch S. The importance of ship hull fouling as a vector of species introductions into the North Sea. Biofouling. 2002;18(2):105-21.

70. Lewis J, Coutts A. Biofouling invasions. In: Dürr S, Thomason JC, editors. Biofouling. Oxford: Wiley-Blackwell; 2010. p. 348-65.

71. Fehlauer-Ale $\mathrm{KH}$, et al. Cryptic species in the cosmopolitan Bugula neritina complex (Bryozoa, Cheilostomata). Zool Scr. 2014;43(2):193-205.

72. Piola RF, Johnston EL. Differential tolerance to metals among populations of the introduced bryozoan Bugula neritina. Mar Biol. 2006;148(5):997-1010.

73. Davidson SK, Haygood MG. Identification of sibling species of the bryozoan Bugula neritina that produce different anticancer bryostatins and harbor distinct strains of the bacterial symbiont" Candidatus Endobugula sertula". Biol Bull Woods Hole. 1999;196(3):273-80.

74. Mcgovern TM, Hellberg ME. Cryptic species, cryptic endosymbionts, and geographical variation in chemical defences in the bryozoan Bugula neritina. Mol Ecol. 2003;12(5):1207-15.

75. Keough MJ, Chernoff H. Dispersal and population variation in the bryozoan Bugula neritina. Ecology. 1987;68:199-210.

76. Wendt DE. Energetics of larval swimming and metamorphosis in four species of Bugula (Bryozoa). Biol Bull Woods Hole. 2000;198(3):346-56.

77. Zabala M, Maluquer P. Illustrated keys for the classification of Mediterranean Bryozoa. Treballs del Museu de Zoologia, Barcelona. 1988;4:1-294.

78. Novosel M, Pozar-Domac A. Checklist of Bryozoa of the eastern Adriatic Sea. Natura Croatica. 2001;10(4):367-421.

79. Gordon D, Mawatari S. Atlas of marine-fouling Bryozoa of New-Zealand ports and harbours. Misc Publ N Z Oceanogr Inst. 1992;107:1-52.

80. Ronowicz M, et al. Temporal and spatial variability of zoobenthos recruitment in a north-east Atlantic marine reserve. J Mar Biol Assoc UK. 2014;94(07):1367-76.

81. Maturo FJS. Bryozoa of the southeast coast of the United States: Bugulidae and Beaniidae (Cheilostomata: Anasca). Bull Mar Sci. 1966;16(3):556-83.

82. Cook PL. Polyzoa from west Africa. The Malacostega, Part I. Bull Br Mus Nat His Zool. 1968;16:116-60.

83. Zabala M. Fauna dels briozous dels Països Catalans. Barcelona: Arxius de la Secció de Ciències, Institut d'Estudis Catalans; 1986. p. 84

84. De Blauwe H. Bryozoa verzameld tijdens de SWG-reis naar Bretagne in April 2005. [Bryozoa collected during the SWG-trip to Brittany in April 2005]. De Strandvlo. 2005:2005(25):76-82.

85. De Blauwe H. Mosdiertjes van de Zuidelijke Bochtvan de Noordzee [Moss animals of the Southern Bight of the North Sea]. Vlaams Instituut voor de Zee. Ostend, pp. 1-464. 2009.

86. Rogick MD, Croasdale H. Studies on marine Bryozoa, III. Woods Hole region Bryozoa associated with algae. Biol Bull. 1949;96(1):32-69. 
87. Calvet L. Contribution à histoire naturelle des Bryozoaires Ectoproctes marins."Travaux de l'institut de zoologie de l'Université de Montpellier et de la station zoologique de Cette Memoire 8: p. 488. 1900.

88. Cohen A, Carlton J. Nonindigenous aquatic species in a United States estuary: a case study of the biological invasions of the San Francisco Bay and delta. A report for the United States Fish and Wildlife Service, Washington, DC, and the National Sea Grant College Program, Connecticut Sea Grant, NTIS Report Number PB96-166525. 1995.

89. MacGillivray PH. Descriptions of new, or little known, Polyzoa. Part 2. Trans Proc R Soc Vict. 1883;19:130-8.

90. Ryland JS. Bryozoa in the Great Barrier Reef Province. Proc Int Coral Reef Symp. 1974;2:341-8.

91. Busk G. Catalogue of marine Polyzoa in the collection of the British Museum. I. Cheilostomata. London: Trustees of the British Museum; 1852. p. 1-54.
92. Florence WK, Hayward PJ, Gibbons MJ. Taxonomy of shallow-water Bryozoa from the west coast of South Africa. Afr Nat Hist. 2007:3:1-58.

93. Harmer S. The Polyzoa of the Siboga Expedition, Part 2, Cheilostomata Anasca. Siboga Exped Rep. 1926;28:183-501.

94. Ramalho LV, Muricy G, Taylor PD. Taxonomy and distribution of Bugula (Bryozoa: Cheilostomata: anasca) in Rio de Janeiro state, Brazil. In: Moyano HIG, Cancino JM, Jackson PNW, editors. Bryozoan studies. Leiden: A.A. Balkema Publishers; 2005. p. 231-43.

95. Keough MJ, Ross J. Introduced fouling species in Port Phillip Bay. In: Hewitt CL, Campbel ML, Thresher RE, Martin RB, editors. Marine Biological Invasions of Port Phillip Bay, Victoria. Hobart: CSIRO Marine Research; 1999. p. 193-226

96. Parry GD, Currie DR, Crookes DP. Exotic marine pests in Portland Harbour and environs. Mar Freshw Resour Inst Tech Rep. 1997;1:1-20.

\section{Submit your next manuscript to BioMed Central and we will help you at every step:}

- We accept pre-submission inquiries

- Our selector tool helps you to find the most relevant journal

- We provide round the clock customer support

- Convenient online submission

- Thorough peer review

- Inclusion in PubMed and all major indexing services

- Maximum visibility for your research

Submit your manuscript at www.biomedcentral com/submit 